УДК $556.1(571.65)+551.345(571.65)$

\title{
К ВОПРОСУ О РЕЖИМЕ ВОДНЫХ ОБЪЕКТОВ ОХОТСКО-КОЛЫМСКОГО ВОДОРАЗДЕЛА
}

\author{
Михайлов В. М. \\ Северо-Восточная научно-исследовательская мерзлотная станщия ФГБУН Института \\ мерзлотоведения им. П. И. Мельникова СО РАН, г. Магадан \\ E-mail:vmmikhailov@gmail.com
}

\begin{abstract}
Рассмотрены ранее не изучавшиеся гидрологические и гидрогеологические проявления мелкоблоковой тектоники на ряде озер и водотоков Северо-Востока России. В исследованиях использованы результаты собственных наблюдений, анализ картографических и аэрокосмических материалов разных лет и литературных источников, опросные сведения. Режим и эволюция изученных объектов проявляют существенную изменчивость на небольших временных интервалах, вплоть до нескольких лет. Они выражаются в сильных колебаниях уровней озер, включая полное их осушение, поглощении руслового стока и ряде других эффектов. Самые неординарные явления следующие: 1) встречно направленные подземный и поверхностный водные потоки на оконечности одного из озер; 2) существование в нижнем течении ручья подземного резервуара, большую часть времени функционирующего в режиме поглощения руслового стока, но эпизодически производящего залповые выбросы воды, многократно превышающие паводочные расходы водотоков сравнимого размера. В многоводные периоды он работает как маломощный источник, дебит которого испытывает суточные колебания под воздействием приливных сил. Многие из изученных объектов расположены на участках с малоконтрастным рельефом, без отчетливых признаков тектонической активности. Несомненно, что наличие таких признаков отнюдь не исключает развитие процессов, аналогичных описанным, - скорее наоборот, хотя в районах с интенсивными и высокоамплитудными подвижками тектонические эффекты малых масштабов оказываются по большей части завуалированными. Вероятно, в гористых местностях и предгорьях они распространены практически повсеместно. Изложенные результаты свидетельствуют о необходимости поиска нестандартных подходов при интерпретации результатов аналогичных наблюдений и использования максимально возможного объема доступных сведений. Практическое значение таких исследований состоит в необходимости учитывать возможность локальных тектонических подвижек при проектировании объектов промышленного и гражданского назначения. Ведущим инструментом при этом должны служить изучение особенностей гидролого-гидрогеологического режима предполагаемых площадок и ретроспективный анализ картографических и аэрокосмических материалов, примеры которого приведены в настоящей работе
\end{abstract}

Ключевые слова: гидрологический режим, гидрогеологические процессы, взаимосвязь поверхностных и подземных вод, эволюция водных объектов, многолетнемерзлые породы, талики, мелкоблоковая тектоника, ретроспективный анализ.

DOI: $10.34078 / 1814-0998-2021-2-68-76$

\section{ВВЕДЕНИЕ}

Влияние блоково-разломной тектоники на поверхностные и подземные воды и их взаимосвязь общеизвестны. Это проявляется в различных пространственных и временных масштабах. Сведения о минимальных значениях обоих показателей разрозненны и не дают адекватного пред-

(C) Михайлов В. М., 2021 ставления об их нижних пределах. Первым значительным шагом в изменении этого положения была работа Д. А. Лилиенберга: «до проведения повторного нивелирования в горах мы, честно говоря, не представляли, что площадная дифференциация современных вертикальных движений может проявляться в блоках с поперечниками всего в несколько сотен метров...» (1993. С. 89 , курсив мой. - В. М.). 
В диссертации (Баранская, 2015) также говорится о дифференцированных движениях блоков размерами в сотни метров, причем автор называет их макроблоками, подразумевая, по-видимому, что это не предельно малые размеры.

В статье С. Д. Шведова отмечен еще более низкий предел тектонической дифференциации. Описывая рельеф грабен-долин, автор сообщает, что их борта «...образованы сбросами, преимущественно ступенчатыми; расстояние между плоскостями сместителей ... колеблется от первых десятков до сотен метров, а амплитуда смещений по ним - от нескольких метров до десятков метров» (2010. С. 14). Меньшие значения, насколько мне известно, в литературе не приводились, если не считать вторичные, производные образования - например, западины на днищах тектонических рвов (Шведов, 2010).

Что касается малых временных масштабов, то, если оставить в стороне явления триггерного характера, т. е. землетрясения, единственные (по-видимому) публикации на эту тему - статьи В. Е. и Л. П. Глотовых $(2008,2012)$. В них анализируются данные об «аномальных гидрографах» зимней межени на ряде рек Северо-Востока России (далее для краткости «Северо-Восток»): на фоне закономерного понижения расходов вплоть до начала снеготаяния могут наблюдаться кратковременные их увеличения. Авторы считают, что подобные флуктуации не могут объясняться ничем иным, как вариациями «...объема емкостного пространства зон разломов, освоенных речными долинами» (2008. С. 77) и связывают их «...с проявлениями современных субгоризонтальных сдвигораздвиговых давлений литосферных блоков в зоне их коллизии» (2012. C. 66). Если учитывать небольшие водосборные площади двух из рассмотренных водотоков (330 и $75 \mathrm{\kappa м}^{2}$ ) и отсутствие какой-либо корреляции между «аномальными гидрографами», то размеры «литосферных блоков» вряд ли могут быть велики.

Цель настоящей работы - изложить ряд фактов, свидетельствующих о необходимости учитывать в исследованиях режима поверхностных и подземных вод и их взаимодействия разнообразные, в том числе ранее не описанные, тектонические процессы, развивающиеся в малых пространственных и (или) временных масштабах.

\section{РАЙОН ИССЛЕДОВАНИЙ, МАТЕРИАЛ И МЕТОДЫ}

Схема расположения участков исследований представлена на рис. 1. Все они принадлежат к бассейну р. Колыма, находясь на небольшом удалении от Охотско-Колымского водораздела и вблизи от границы Охотско-Чукотского вулка- ногенного пояса с Верхояно-Колымской складчатой системой. На участках № 1 и 4 преобладают вулканогенные разности с участием песчаноглинистых сланцев; на остальных соотношение обратное. Карстующиеся породы, наиболее благоприятные для развития вертикального водообмена, отсутствуют. В геоморфологическом отношении участки расположены в низко- и среднегорье, в небольших понижениях рельефа.

Согласно районированию А. И. Калабина (1960), все участки принадлежат к области сплошной криолитозоны, располагаясь к северу от границы между II и III мерзлотными районами. Мощность многолетнемерзлых пород (ММП) в понижениях рельефа составляет здесь 100 м и более, температура $-1.5^{\circ} \mathrm{C}$ и ниже. Сквозные талики формируются под крупными непромерзающими реками и озерами (хотя здесь они могут носить застойный характер), а также на участках питания и выхода подмерзлотных вод.

Проявления новейшей и современной разломно-блоковой тектоники на Северо-Востоке России многочисленны. Большинство разрывных нарушений группируются в ряд систем (Горячев и др., 2016); для территории, включающей участки наблюдений, они подробно показаны в работе (Калинина, Смирнов, 2017) на рис. 1, а наиболее активные разломы - в издании (Карта..., 2020). Согласно последнему источнику, на оконечности одного из второстепенных разломов расположен участок № 2, для остальных совпадений с закартированными разломами нет.

Обсуждаемые ниже факты получены в результате собственных наблюдений, анализа картографических и аэрокосмических материалов и литературных источников; использованы также опросные сведения. Для всех описанных ниже

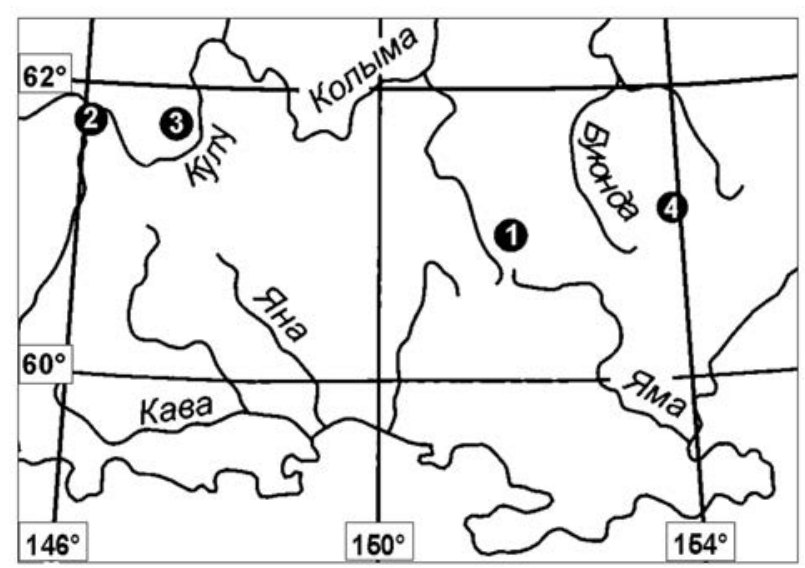

Puc. 1. Схема расположения исследованных участков. Нумерация соответствует порядку изложения при описании результатов наблюдений

Fig. 1. Layout of the researched sites, numbered according to the order of presentation when describing the results of observations 
объектов приведены их географические координаты, что позволяет читателю получить о них собственное представление при помощи сервисов Google Earth и nakarte.me; для водотоков, при отсутствии специальных оговорок, координаты относятся к устьям.

\section{РЕЗУЛЬТАТЫ ИССЛЕДОВАНИЙ}

1. Оз. Черное $\left(61^{\circ} 01^{\prime} 15^{\prime \prime}, 151^{\circ} 44^{\prime} 19^{\prime \prime}\right)$ и близлежащее оз. Приятное $\left(61^{\circ} 01^{\prime} 31^{\prime \prime}, 151^{\circ} 42^{\prime} 54^{\prime \prime}\right)$. Оба они подробно описаны в работе (Ложкин и др., 2000); там же приведены результаты послойных радиоуглеродных и спорово-пыльцевых анализов донных осадков. Приводимые ниже численные сведения, дополненные результатами собственных наблюдений и оценок, взяты из этой работы. Ее авторы считают, что «полученные материалы позволили ... подойти к решению вопроса о происхождении и эволюции озер» (С. 21). Ниже (C. 33) сообщается: «оз. Приятное объединяет два генетически различных бассейна - восточный и западный». В восточном, где глубины изменяются от 3 до 5 м, мощность донных осадков не превышает 35 см. Далее речь идет только о менее глубоком (до 3.5 м) западном бассейне, дно которого покрыто на порядок более мощным слоем озерных отложений (385 см). В заключительной части статьи утверждается, что «оз. Приятное... в течение голоцена развивалось (как целое? - В. М.) как термокарстовое» (С. 44). Это противоречит постулированному выше и оставшемуся без обоснования генетическому различию двух бассейнов.

Если экстраполировать сведения по западному бассейну, то время накопления осадков в восточном оценивается в 1300 лет, т. е. он образовался на 27.5 тыс. лет позже. По мнению авторов, «оз. Приятное возникло... как ледниковое

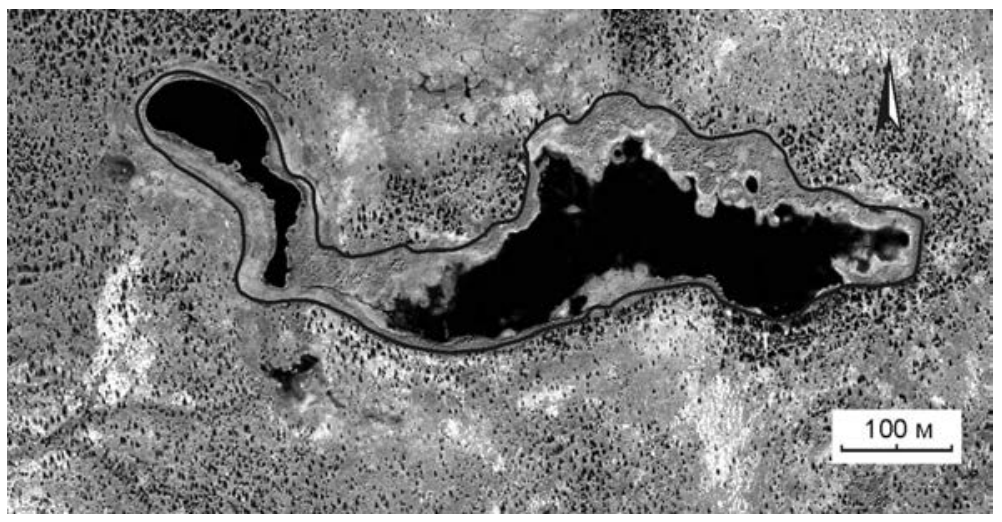

Puc. 2. Космический снимок оз. Приятное (Google Earth) в июле 2019 г. Контуром показана береговая линия по аэрофотоснимку 1980 г.

Fig. 2. Space photo of Lake Priyatnoye (Google Earth), July 2019. The outline shows the coastline according to the air photo taken in 1980 в чаше, образованной моренами...» (С. 43), т. е. западный бассейн изначально имел не нулевую глубину. Восточный был лишен этого стартового преимущества, однако почти наверстал отставание за несравненно более короткий срок («почти»- принимая в расчет разницу в мощности накопленных донных осадков). Если считать, что оба бассейна разрастались и углублялись исключительно за счет вытаивания ледяных жил, то различия в скорости роста (восточный к тому же вдвое больше по площади) не находят объяснения.

Всё становится на свои места, если принять, что восточный бассейн имеет тектоническое происхождение. Этому имеется убедительное подтверждение. Сотрудники Института биологических проблем Севера ДВО РАН, регулярно посещавшие оз. Приятное в целях вылова беспозвоночных, в июне 2009 г. обнаружили, что оно стало совершенно безжизненным из-за сильного обмеления и последующего зимнего промерзания (Г. И. Атрашкевич, устное сообщение). Максимальная толщина льда на аналогичном по морфологическим характеристикам якутском оз. Чурапча за весь период наблюдений равна 1.63 м (Многолетние..., 1987). Вблизи от оз. Приятное (метеостанция Атка) зимы намного теплее; по данным соответствующих Справочников по климату (1966), в январе разница была равна $12.5^{\circ}$. Следовательно, для полного промерзания этого озера сработка уровня должна была составить как минимум 3.5 м. Поскольку водоем не имеет поверхностного стока, то она могла произойти только за счет расширения и (или) углубления дренирующего озеро талика.

В 2009 г. озеро представляло собой два разобщенных бассейна с признаками периодического слабого перетока воды из западного в восточный (цитируя автора сообщения, по «грязевой канаве»). Аналогичная ситуация читается на космоснимке, сделанном в июле 2019 г. (рис. 2). Но при этом по результатам собственного обследования в сентябре 2013 г. озеро имело очертания, близкие к наблюдаемым ранее (аэрофотоснимок августа 1980 г.), с уровнем примерно на 1.5 м ниже максимального за всё время существования.

В свете изложенного эволюция восточного бассейна представляется следующей: он образовался независимо от давно существовавшего западного в результате тектонического опускания прилегающего участка. От опустившегося блока коренных пород в северном направлении протягивается разлом, над которым вследствие раз- 
уплотнения перекрывающих флювиогляциальных отложений сформировался водопроводящий талик. В свое время он не препятствовал наполнению озера до максимальных отметок, а впоследствии (во всяком случае, большую часть времени) не давал ему ни переполняться, ни срабатываться до уровня, допускающего зимнее промерзание. В 2008 г. произошла активизация разлома, проявляющаяся в сильной изменчивости водопропускной способности талика.

Этот талик (точнее, его водопроводящая часть) проходит близко к поверхности, что препятствует осушению, хотя бы временному, восточного бассейна. Здесь талик заканчивается, так что сток паводочных вод из западного бассейна происходит поверхностным путем. «Грязевая канава» постепенно углубляется вследствие размыва, обнажающего крупнообломочные флювиогляциальные отложения.

Озеро Черное по времени своего возникновения занимает промежуточное положение между двумя рассмотренными выше бассейнами (Ложкин и др., 2000). Есть основания считать, что в его эволюции в прошлом принимали активное участие тектонические факторы. Это, например, резкие перепады гипсометрических отметок между берегом озера и его дном. Так, у самого отлогого берега, где берет начало небольшой ручей, глубины превышают 4 м, тогда как на большей части акватории они близки к 1 м, а самый высокий участок берега круто обрывается к плоскому отмелому дну, на котором многочисленны погибшие, т. е. затопленные, лиственницы. В образовавшемся здесь обнажении высотой 12-15 м вскрыты осадки, подобные тем, что подстилают отложения самого озера, начиная с глубины 285 см. Разность отметок кровли этого слоя под озером и в обнажении составляет около $12 \mathrm{м}$.

Яркое проявление тектоники - выход скальных пород (риолит) на единственном небольшом пляже (рис. 3). Согласно результатам подробных исследований, отраженным на геоморфологической схеме (Ложкин и др., 2000), коренное основание здесь перекрыто толщей древних озерных отложений мощностью в десятки метров. Этот скальный выступ является не статичным, а растущим образованием. Он служит источником крупнообломочного материала (слабо окатанные дресва и щебень) для примерно половины побережья озеpa. Непосредственно в месте выхода многочисленны невыветрелые глыбы. Верхушка выступа, по-видимому, регулярно срезается вследствие вол- ноприбойной деятельности до приблизительно единого уровня с вмещающими мелкоземистыми отложениями.

Озера Черное и Приятное расположены недалеко от подробно изученного активного Хетинского разлома (Кондратьев, Смирнов, 2010; Смирнов, Кондратьев, 2011), но согласно схеме, приведенной в первой из работ (С. 207), они находятся за пределами предполагаемой области динамического влияния разлома.

2. Оконечность открытой долины между оз. Хадды и р. Кулу, некогда занятой ледником. Среди многочисленных мелководных озер, днища которых покрыты песчано-илистыми осадками, контрастно выделяются два близлежащих к реке озерца с отсутствием таких отложений диаметром примерно по 100 м (6145'50", 14600'41" средняя точка). Снимок (рис. 4) сделан в период с умеренными осадками; очевидно, что в межень водоем полностью осушается, а после продолжительных дождей или бурного снеготаяния его чаша наполняется до краев, имея глубину около 2-3 м. В полную воду озерца соединяются и, вероятно, эпизодически имеют поверхностный сток. По снимку хорошо видно, что отток воды происходит главным образом подземным путем, сопровождаясь неравномерным выносом поступившего вместе с ней мелкозема и образовавшихся на месте продуктов выветривания (вплоть до песка и мелкого гравия). Созданный в результате радиально-полосчатый рисунок днища явно маркирует чередование участков с высокой и пониженной водопоглощающей способностью и соответственными вариациями трещиноватости скальных пород.

Ложа этих водоемов - единственное место во всей долине, где на ее дне были обнаружены крупные обломки коренных пород. Если озерца

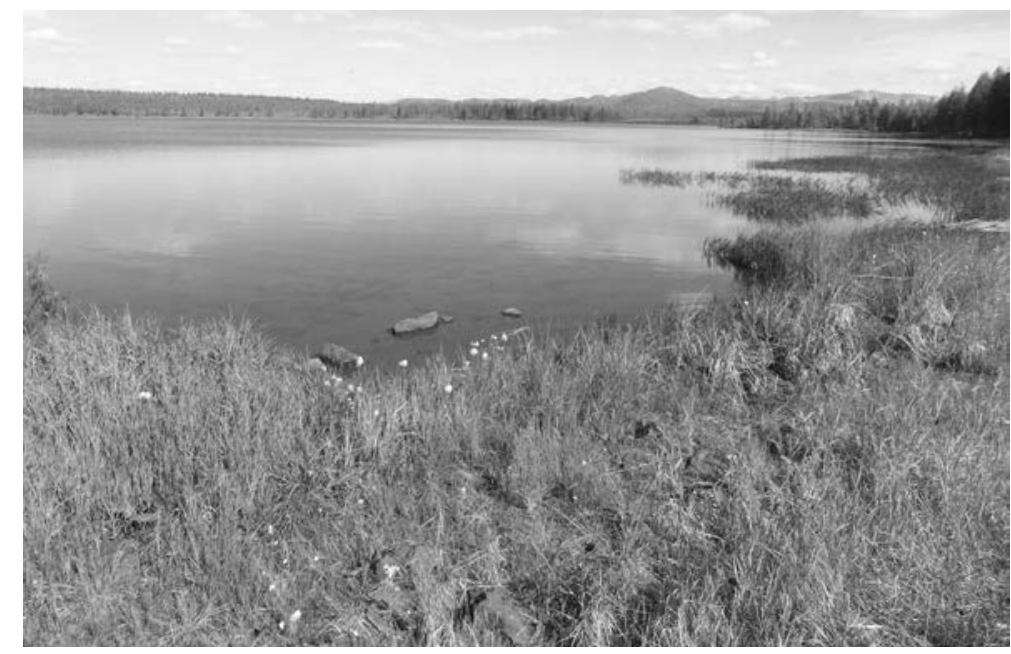

Puc. 3. Выход коренных пород на низменном берегу оз. Черное Fig. 3. Bedrock outcrop on the low shore of Lake Chornoye 


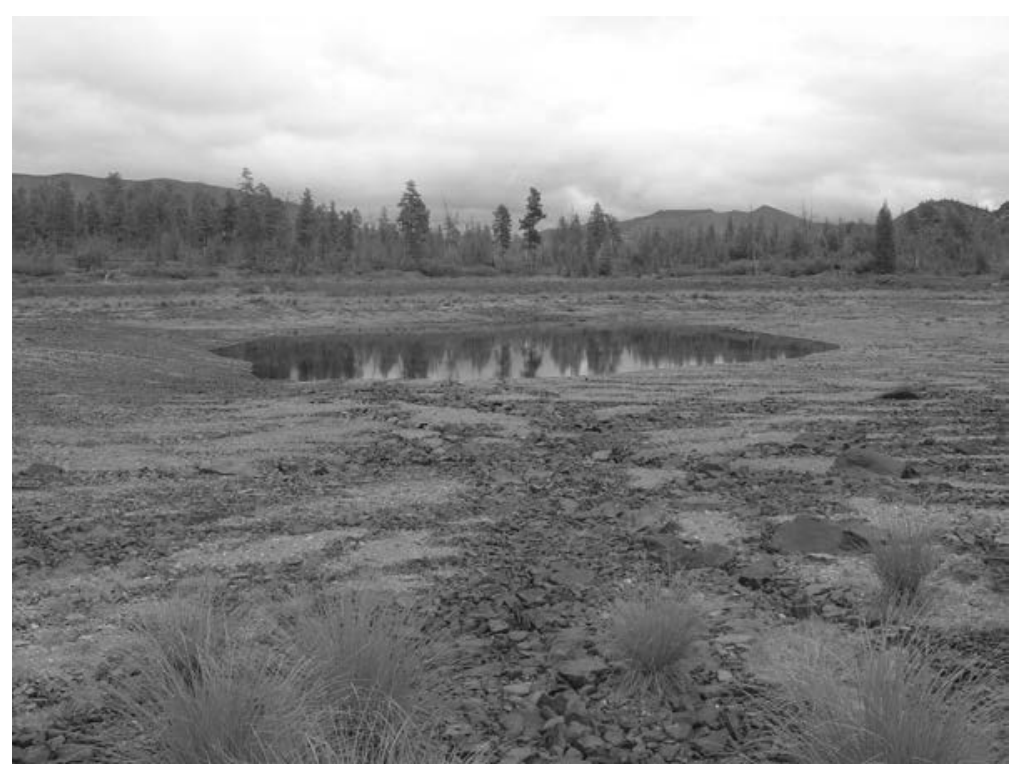

Рис. 4. Озерцо на оконечности открытой долины вблизи от р. Кулу

Fig. 4. Small lake at the end of an open valley near the Kulu River

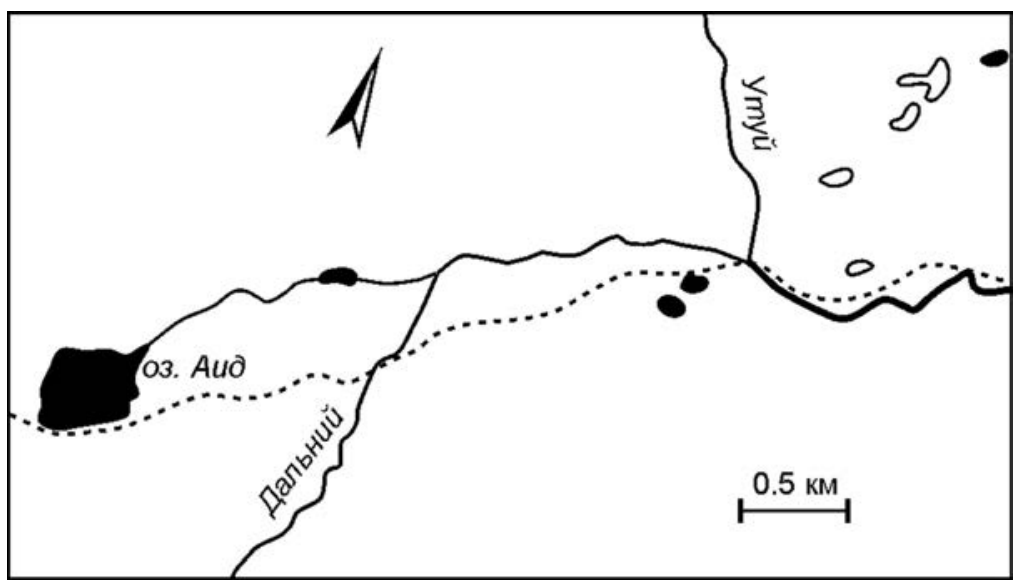

Puc. 5. Гидрографическая схема окрестностей оз. Аид по карте масштаба 1:100 000 с учетом позднейших изменений, пунктиром обозначена грунтовая дорога. Контуры без заливки - водоемы, исчезнувшие между 2006 и 2016 г.

Fig. 5. Hydrographic scheme of Lake Aid vicinities according to the 1:100 000 scale map, considering later changes; dotted line shows the dirt road. Unfilled outlines mark the ponds vanished between 2006 and 2016

образовались сразу в виде, близком к современному, то, следовательно, почти весь объем песчаного и более мелкого материала, накопленного над ними в теле ледника, после его таяния был удален через водопроводящие пути в подстилающих породах. Эти пути должны были обладать исключительно высокой пропускной способностью, намного большей по сравнению с современной. Такое предположение выглядит малоправдоподобным, что приводит к следующему выводу: ранее на месте озерец существовали куполообразные возвышения (отсюда радиальная трещино- ватость), с которых мелкий материал был снесен.

3. О3. Аид $\left(61^{\circ} 46^{\prime} 52^{\prime \prime}, 146^{\circ} 29^{\prime} 15^{\prime \prime}\right)$ с протекающими поблизости руч. Утуй и Дальний. Оно расположено вблизи от северо-восточной оконечности открытой долины, носящей следы ледниковой деятельности. Исследования, проведенные в 2006 г., показали, что на топографических картах этой местности (рис. 5) имелись сразу две неточности.

Во-первых, руч. Дальний в нижнем течении вовсе не протекает по открытой долине, принимая далее в качестве притока руч. Утуй, не уступающий ему по площади водосбо-

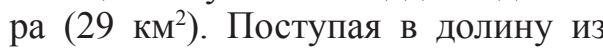
бокового распадка, Дальний в межень впитывается в грунт на пологом шлейфе ее правого склона вблизи от пересечения с грунтовой дорогой (см. рис. 5). В паводки, судя по отложенному вдоль дороги и поблизости гравийно-галечному материалу, ручей протекает по ней на протяжении до 150 м, давая в сторону тальвега ответвления, которые иссякают уже на небольшом удалении. В самом тальвеге, проходящем под крутым левым бортом долины, следы деятельности текучих вод отсутствуют, хотя прилегающая к нему полоса выделяется более густой растительностью вследствие лучшего увлажнения. Не исключено, что на аэрофотоснимках, использованных при составлении топографических карт, ручей действительно протекал по тальвегу долины; в пользу такого предположения свидетельствуют ландшафтные признаки, свойственные внутренним дельтам, в пункте «слияния ручьев». В настоящее время ручей со всеми ответвлениями целиком впитывается в грунт далеко от тальвега долины. Но выполняющие ее ледниковые отложения изначально обладали низкими фильтрационными свойствами, что обеспечивало существование восьми мелких водоемов (см. рис. 5). Отсюда вывод: исчезновение руч. Дальний связано с расширением разломов в днище долины и разуплотнением маломощного слоя перекрывающих рыхлых отложений, причем этот процесс развит на значительном удалении от тальвега (200-300 м).

Во-вторых, озеро не проточное. Точнее, оно не имеет поверхностного стока, принимая при- 
токи на обеих своих оконечностях - отсюда, повидимому, данное первопроходцами название. Несмотря на небольшую площадь водосбора (11 км²), озеру необходимо избавляться от излишков воды, и иного пути, кроме подземного стока, для этого нет. Получается, что у северовосточной оконечности озера поверхностный и подземный потоки направлены встречно. Но это возможно только при полном отсутствии между ними гидравлической связи. Следовательно, дренирующий озеро разлом либо проходит далеко в стороне от тальвега долины (но не далее 200 м), либо имеет водоупорную кровлю.

Из существовавших ранее, как минимум до 2006 г., 8 малых водоемов на космоснимке 2016 г. половина отсутствует (см. рис. 5). Очевидно, что они стали в лучшем случае эфемерными образованиями, т. е. вода, стекающая в них во время снеготаяния (и в каком-то объеме накапливающаяся), далее по мере протаивания грунта поглощается новообразованным или омоложенным разломом (группой разломов).

4. Руч. Заозерный с площадью водосбора 10.2 км $^{2}\left(61^{\circ} 10^{\prime} 21^{\prime \prime}, 153^{\circ} 52^{\prime} 51^{\prime \prime}\right)$, впадающий в о3. Энгтери. На удалении от устья более 200 м это обычный водоток второго порядка, протекающий в устойчивых берегах, покрытых моховотравяной растительностью, с небольшими галечными пляжами. Однако на приустьевом участке, после крутого левого поворота, картина резко меняется. При первом обследовании в июле 2017 г. сток здесь полностью отсутствовал, зато имелись отчетливые следы недавней деятельности бурного потока, интенсивно размывавшего берега и нагромоздившего ряд древесных завалов (рис. 6; снимок сделан при повторном обследовании в 2019 г.). В аналогичной физико-географической обстановке паводочные расходы, производящие подобную работу, характерны для рек с водосборными площадями в сотни квадратных километров.

Имеющиеся сведения позволяют утверждать, что катастрофический паводок, кардинально преобразовавший русло ручья в нижнем течении, не был единичным событием. Этот участок отчетливо выделяется на аэрофотоснимке 1969 г., имея такую же протяженность. Следовательно, в обозримый промежуток времени здесь прошли как минимум два подобных паводка: один незадолго до 1969 г., второй сравнительно недавно - иначе за истекший полувековой период единожды перемытый аллювий успел бы покрыться травами и кустарниками с древесным подростом.
Во время обследования в июне 2019 г. вода в ручье была обнаружена примерно в 100 м от озера; вверх по течению расход постепенно возрастал до максимума при переходе к устойчивому руслу. Граница сухого и обводненного участков не оставалась постоянной: фронт смачивания продвигался вниз по тальвегу со скоростью около $1 \mathrm{~cm} / \mathrm{c}$. На следующий день он отступил вверх по течению приблизительно на 30 м, но при этом вновь перемещался вниз с той же скоростью. Подобные квазипериодические колебания на первый взгляд напоминают режим рек с ледниковым питанием, у которых расход воды ежесуточно изменяется вслед за усиленным таянием льда днем и ночным его ослаблением; в роли отсутствующих ледников могли бы выступать сохранявшиеся снежники. Но на время наблюдений они занимали не более 2-3 \% площади бассейна и были хаотично распределены по территории (в зависимости от экспозиции склонов). Из-за низкой суммарной интенсивности таяния и очевидной асинхронности поступления талых вод в низовья водотока снежники совместно с суточными колебаниями температуры воздуха никак не могли обусловливать наблюдаемую картину.

Своеобразие гидрологического режима ручья объясняется, по-видимому, наличием подземного резервуара, обладающего весьма неординарными свойствами. Обычно он поглощает значительную часть руслового стока, но время от времени производит мощные залповые выбросы воды, на порядок превосходящие максимальные расходы, характерные для ручьев сравнимой водности. Такие выбросы вряд ли можно объяснить иначе как тектоническими подвижками, резко уменьшающими объем резервуара. Что касается еже-

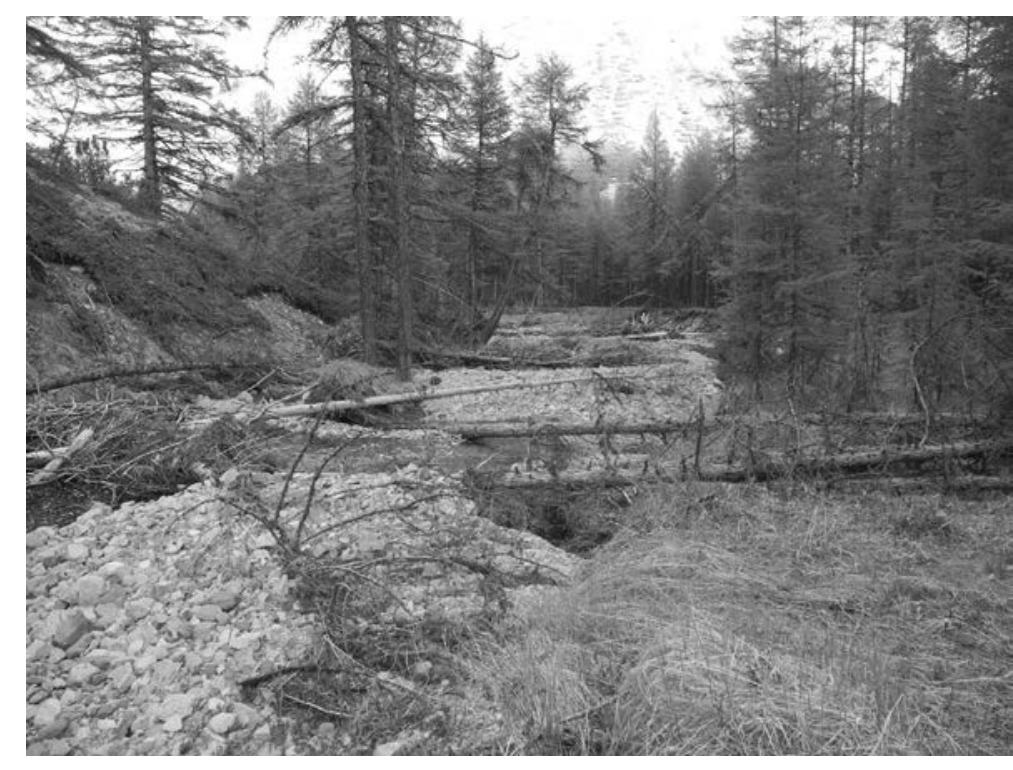

Puc. 6. Нижнее течение руч. Заозерный в межень

Fig. 6. Lower reaches of the Zaozerny Creek in low water 
суточных вариаций поглощения / подпитки поверхностных вод, то единственным (помимо отвергнутых метеоусловий) суточно-ритмическим фактором, причем действующим повсеместно, являются приливные волны, пронизывающие, в том числе, и «земную твердь». Влияние приливов на дебиты источников подземных вод описано, например, в работе (Осокин, 1980).

\section{ОБСУЖДЕНИЕ РЕЗУЛЬТАТОВ}

При обсуждении изложенных выше фактов и их интерпретации высказывались мнения о том, что рассматриваемые процессы и явления могут иметь в своей основе иную, не тектоническую природу. В качестве альтернатив выдвигались: для механизма формирования таликов - сезонное и многолетнее протаивание ММП, вытаивание жильных льдов; для вариаций уровенного режима озер - погодные и климатические изменения на их водосборах. Далее приводится критический анализ этих предположений.

1. Формирование таликов. Сезонное протаивание ММП на территории исследований ограничено в понижениях рельефа величинами, редко превышающими первые метры, и поэтому никак не может служить причиной каких-либо из наблюдаемых гидролого-гидрогеологических эффектов.

Многолетнее протаивание, в том числе сопровождаемое вытаиванием жильных льдов, может осуществляться путем кондуктивной теплопроводности при наличии адекватных источников тепла. Таковыми на рассматриваемой территории являются лишь достаточно крупные реки и озера; при их размерах, намного больших мощности ММП, формируются сквозные талики. Из исследованных водных объектов этому критерию отвечает оз. Черное с поперечником 770 м и, скорее всего, оз. Аид (390 м). Озеро Приятное в 1980 г. имело ширину 180 м, и здесь существование сквозного талика сомнительно. Таких таликов безусловно нет под двумя неглубокими озерцами на участке № 2 .

Но наличие талика, даже сквозного, само по себе не обеспечивает тесного взаимодействия поверхностных и подземных вод, что видно на примере оз. Черное, которое дренируется небольшим ручьем, в засушливые периоды почти пересыхающим. Колебания уровня в этом водоеме составляют 20-30 см. Наоборот, под вышеупомянутыми озерцами, явно время от времени осушаемыми, за счет кондуктивной теплопроводности могли сформироваться лишь неглубокие чаши протаивания. Они не способны обеспечить отток поверхностных вод без соединения с вытянутыми в плане межмерзлотными таликами (скорее, одним и тем же таликом) либо развития подозерных таликов в сквозные. Оба варианта предполагают действие тектонических факторов.
Под оз. Аид талик вполне может существовать только за счет кондуктивного механизма теплопередачи, при этом его плановые очертания должны примерно соответствовать береговой линии. Но озеро имеет подземный сток по некоему водопроводящему образованию, которое протягивается вниз по открытой долине как минимум до пересечения с руч. Утуй (на 2.8 км). Оно, несомненно, связано с разломом, который либо сам выполняет роль канала стока, либо обусловливает разуплотнение вышележащих рыхлых пород и повышение их проницаемости. Таким образом, здесь имеет место комбинация водопоглощающего подозерного талика и водопроводящего межмерзлотного талика или, возможно, водопроводящей зоны, расположенной ниже подошвы ММП. Не исключено также, что подозерный талик не участвует в дренировании водоема, который непосредственно соединяется с межмерзлотным таликом. Сходное образование, проходящее субпараллельно, поглощает сток руч. Дальний при его выходе в открытую долину.

Как отмечено в предыдущем разделе, в период между 2006 и 2016 г. в этой долине практически исчезли 4 из 8 мелких водоемов (см. рис. 5), в том числе самый крупный с поперечником около 100 м и глубиной более 1.5 м. Остальные семь на время обследования в 2006 г. были намного меньше и мельче (менее 1 м в самых глубоких местах) и явно промерзали на зиму. Признаки значительных вариаций уровней в 2006 г. отсутствовали во всех водоемах, а четыре сохранившихся в 2016 г. имели приблизительно прежние размеры.

По сумме признаков, под всеми водоемами могли существовать лишь неглубокие чаши протаивания. Следовательно, исчезнувшие озерца были сдренированы новообразованными разломами, и водопоглощающие талики продолжали существовать по меньшей мере до 2016 г. Поскольку их взаиморасположение весьма далеко от прямой линии, то речь, по-видимому, должна идти не менее чем о двух разломах.

Таким образом, на небольшом протяжении открытой долины наблюдается ряд вариантов взаимодействия поверхностных и подземных вод, обусловленных активной мелкоблоковой тектоникой.

2. Вариации уровней озер. Время существования оз. Приятное измеряется тысячами лет. Поэтому спонтанная сработка его уровня в 2008 2009 гг. за не более чем полугодовой отрезок времени исключает обусловленность этого явления климатическими изменениями. Аналогия с исчезнувшими водоемами на участке № 3 очевидна. Последующие короткопериодные вариации уровней в оз. Приятное, а также в двух озерцах на участке № 2 безусловно связаны с погодными условиями (снеготаяние и режим вы- 
падения осадков). Но в близлежащих водоемах, как в крупном оз. Черное, так и в более мелких, чем озерца при максимальном наполнении, признаков сколько-нибудь существенных колебаний уровней нет. Следовательно, уровенный режим этих трех объектов дополнительно регулируется оттоком вод по таликам, связанным с тектоническими нарушениями.

\section{ЗАКЛЮЧЕНИЕ}

Рассмотренные примеры демонстрируют широкое разнообразие гидрологических и гидрогеологических процессов и явлений, обусловленных новейшими и современными тектоническими движениями, развивающимися в небольших пространственно-временных масштабах. Одни из них не имеют описанных в литературе аналогов; другие не находят исчерпывающего объяснения в свете имеющейся информации.

Большинство изученных объектов расположено на участках с малоконтрастным рельефом, при отсутствии связи с более крупными тектоническими нарушениями и отчетливых признаков тектонической активности. Несомненно, что наличие таких признаков отнюдь не исключает развитие процессов, аналогичных описанным, скорее, наоборот, хотя в районах с интенсивными и высокоамплитудными подвижками тектонические эффекты малых масштабов оказываются завуалированными. Вероятно, в гористых местностях и предгорьях они распространены практически повсеместно.

В совокупности изложенные результаты свидетельствуют о необходимости поиска нестандартных подходов при интерпретации результатов аналогичных наблюдений и использования максимально возможного объема доступных сведений.

Практическое значение таких исследований состоит в необходимости учитывать возможность локальных тектонических подвижек при проектировании объектов промышленного и гражданского назначения. Ведущим инструментом при этом являются изучение особенностей гидролого-гидрогеологического режима предполагаемых площадок и ретроспективный анализ картографических, аэрофото- и космических материалов, примеры которого приведены в настоящей работе.

\section{БЛАГОДАРНОСТИ}

Автор признателен сотрудникам ИБПС ДВО РАН К. В. Регель и Г. И. Атрашкевичу за многочисленные устные сведения об эволюции оз. Приятное и фотоснимки, их иллюстрирующие.

Поступила в редакциию 29.09.2020 2.

Поступила после доработки 28.02.2021 2.

\section{ЛИТЕРАТУРА}

Баранская A. В. Роль новейших вертикальных тектонических движений в формировании рельефа побережий российской Арктики : дис. ... канд. геогр. наук. Санкт-Петербург, 2015. 236 с.

Глотов В. Е., Глотова Л. П. Естественные нарушения поземного питания рек бассейна Верхней Колымы в зимнюю межень // Криосфера Земли. 2008. Т. 7, № 1. C. 72-78.

Глотов В. Е., Глотова Л. П. Роль подземных вод в формировании стока рек Примагаданского шельфа // Криосфера Земли. 2012. Т. 16, № 4. С. 57-66.

Горячев А. Н.,. Пальмский Б. Ф., Петров А. Н., Хасанов И. М. Ансамбли разломов Охотско-Колымского региона // Вестник Северо-Восточного научного центра ДВО РАН. 2016. № 1. С. 3-15.

Калабин А. И. Вечная мерзлота и гидрогеология Северо-Востока СССР. Магадан : ВНИИ-1, 1960. 470 с. (Тр. ВНИИ-1; т. 18).

Калинина Л. Ю., Смирнов В. Н. Количественный анализ связи землетрясений с относительной амплитудой активных разломов на юго-восточном фланге сейсмического пояса Черского // Вестник Северо-Восточного научного центра ДВО РАН. 2017. № 2. С. 24-29.

Карта активных разломов. Лист Р-55-56. Сусуман. Источник: База данных активных разломов Евразии (AFEAD). Масштаб: 1:1 000 000. 2020. http:// neotec.ginras.ru/database.html

Кондратьев М. Н., Смирнов В. Н. Кинематический анализ Хетинского активного разлома // Проблемы сейсмичности и современной геодинамики Дальнего Востока и Восточной Сибири. Хабаровск : ИТиГ ДВО PAH, 2010. C. 206-208.

Лилиенберг Д. А. Пространственно-временные проявления современной эндодинамики рельефа и их взаимосвязь с экзодинамикой (на примере горных стран) // Развитие рельефа и его устойчивость. Москва : Наука, 1993. С. 87-97.

Ложкин А. В., Андерсон П. М., Глушкова О. Ю., Соломаткина Т. Б., Фелерова И. Н. О некоторых особенностях развития озер в горных районах Верхней Колымы // Берингия в четвертичный период. Магадан : СВКНИИ ДВО РАН, 2000. С. 20-45.

Многолетние данные о режиме и ресурсах поверхностных вод суши. Ленинград : Гидрометеоиздат, 1987. Т. 1. Вып. 16. 595 с.

Осокин В. Д. Экспериментальные исследования приливных колебаний дебита термальных источников // Изв. АН СССР. Физика Земли. 1980. № 3. С. 78-82.

Смирнов В. Н., Кондратьев М. Н. Поле напряжений и внутренняя структура Хетинского активного разлома // Вестник Северо-Восточного научного центра ДВО РАН. 2011. № 4. С. 65-72.

Справочник по климату СССР. Ленинград : Гидрометеоиздат, 1966.

Вып. 24. Ч. 2. Температура воздуха и почвы. 398 с.

Вып. 33. Ч. 2. Температура воздуха и почвы. 398 с.

Шведов С. Д. Неотектонические разломы Килганских гор и новейшая геодинамика (Северо-Восточное Приохотье) // Вестник Северо-Восточного научного центра ДВО РАН. 2010. № 4. С. 12-19. 


\title{
ON THE PROBLEM OF THE REGIME AND EVOLUTION OF WATER BODIES IN THE AREA OF THE OKHOTSK-KOLYMA WATER DIVIDE
}

\author{
V. M. Mikhailov
}

\author{
North-Eastern Permafrost Research Station of the Melnikov Permafrost Institute, SB RAS, Magadan
}

\begin{abstract}
The article discusses previously unexplored hydrological and hydrogeological manifestations of smallscale tectonics on a number of lakes and streams in the North-East of Russia. The research involves the results of the author's own observations, analysis of cartographic and aerospace materials of different years as well as published and interrogation data. Regime and evolution of the investigated objects display significant (to several years) variability within short time intervals, manifested in intense fluctuations of water levels in lakes, including their complete draining, absorption of rivers flow, and a number of other effects. The most unusual of them are: 1) counter-directed underground and surface water flows at one of the lakes' extremity; 2) an underground reservoir existence in low reaches of a stream. Most of the time, it drains the surface flow but occasionally it generates volleys of water many times exceeding the extreme floods on streams of comparable sizes. In high-water periods, it functions as a low-debit spring whose output oscillates daily under the influence of tidal force. Many of the studied objects are situated in localities of low-contrast relief without distinct features of tectonic activity. Undoubtedly, the presence of such features does not exclude the processes similar to the abovementioned, though in areas with intense and high-amplitude tectonic movements they are mostly obscure. Probably, in mountainous parts, including foothills, they are widespread. The results presented indicate the need for searching unconventional approaches to interpreting similar observations and using the maximum possible amount of available information. Practical importance of such studies is implied by the necessity to consider the possibility of local tectonic movements when designing industrial and civil objects. The leading inventory in this case should be the study of hydrological and hydrogeological peculiarities of regimes at the sites proposed and the retrospective analysis of cartographic and aerospace materials, examples of which are presented in this paper.
\end{abstract}

Keywords: hydrological regime, hydrogeological processes, relationship between surface and ground waters, evolution of water bodies, permafrost, taliks, small-block tectonics, retrospective analysis.

\section{REFERENCES}

Baranskaya, A. V., 2015. Role of the Latest Vertical Tectonic Movements in the Formation of the Russian Arctic Coast Reliefs: Dis. ... Candidata Geograph. Nauk. St. Petersburg [In Russian].

Glotov, V. Ye., Glotova, L. P., 2008. Natural Disturbances of the Groundwater Supply to the Upper Kolyma Basin Rivers in the Winter Low Water, Earth's Cryosphere. 12 (1), 72-78 [In Russian].

Glotov, V. Ye., Glotova, L. P., 2012. Role of Groundwaters in the Formation of the River Flow in the Magadan Shelf, Earth's Cryosphere.16 (4), 57-66 [In Russian].

Goryachev, N. A., Palymsky, B. F., Petrov, A. N., Khasanov, I. M., 2016. Fault Ensembles in the Okhotsk-Kolyma Area, Vestnik NESC FEB RAS. 1, 3-15 [In Russian].

Handbook of the Climate of the USSR, 1966. Leningrad, Gidrometeoizdat [In Russian].

Iss. 24. Part 2. Water and Soil Temperature.

Iss. 33. Part 2. Water and Soil Temperature.

Kalabin, A. I., 1960. Permafrost and Hydrogeology in the North-East of the USSR Magadan, VNII-1 (Transactions of VNII-1, Vol. 18) [In Russian].

Kalinina, L. Yu., Smirnov, V. N., 2017. Quantitative Analysis of the Relationship between Earthquakes and the Relative Amplitude of Active Faults at the Southeastern Flank of the Chersky Seismic Belt, Vestnik NESC FEB RAS. 2, 24-29 [In Russian].

Kondratyev, M. N., Smirnov, V. N., 2010. Kinematic Analysis of the Kheta Active Fault, Problems of Seismicity and Modern Geodynamics of Far East and East Sy- beria. Khabarovsk, ITiG DVO RAN. 206-208 [In Russian].

Lilienberg, D. A., 1993. Space-Time Manifestations of the Modern Relief Endodynamics and Their Interrelation with Exodynamics (Exemplified by Mountainous Countries), Relief Development and Stability. Moscow, Nauka. 87-97 [In Russian].

Long-Term Data on the Regime and Resources of Land Surface Waters, 1987. Leningrad, Gidrometeoizdat. Iss. 16, 1 [In Russian].

Lozhkin, A. V., Anderson, P. M., Glushkova, O. Yu., Solomatkina, T. B., Felerova, I. N., 2000. On Some Features of Lake Development in Mountain Areas of the Upper Kolyma, Beringia in Quaternary. Magadan, NEISRI FEB RAS. 20-45 [In Russian].

Map of Active Faults. Sheet P-55-56 Susuman. Source: Database of Active Faults of Eurasia and Adjacent Aquatories (AFEAD). Scale: 1:1 000 000. 2020. http://neotec. ginras.ru/database.html

Osokin, V. D., 1980. Experimental Research of Tidal Oscillations of Thermal Springs' Output, Izvestiya $A N$ USSR, Physics of the Earth. 3, 78-82 [In Russian].

Shvedov, S. D., 2010. Neotectonic Faults of the Kilgana Mountains and Modern Geodynamics (North-Eastern Priokhotye ), Vestnik NESC FEB RAS. 4, 12-19 [In Russian].

Smirnov, V. N., Kondratyev, M. N., 2011. Stress Field and the Internal Structure of the Kheta Active Fault, Vestnik NESC FEB RAS. 4, 65-72 [In Russian]. 